\title{
A Study of Contribution of Aga Khan Education Services Pakistan for Primary Education
}

\author{
Dr. Sufiana. K. Malik \\ Assistant Professor, Education Department \\ National University of Modern Languages Islamabad, Pakistan \\ E-mail: education_peace@yahoo.com \\ Nadia Bi bi \\ Education Department \\ National University of Modern Languages (NUML) Islamabad, Pakistan
}

Received: January 25, 2011 Accepted: April 1, $2011 \quad$ doi:10.5539/ass.v7n8p133

\begin{abstract}
Paper determines contribution of Agha Khan Education Services Pakistan (AKESP) for primary education at Chitral. Findings indicated that AKESP primary schools provide free admission for all students. Teachers at AKESP primary schools are highly qualified; they are provided refreshes courses, AKESP schools have proper building, furniture, electricity, computer, library, sick room, drinking water and proper toilet facilities. Scholarships are given to outstanding students and fee concession facility for poor students. Findings depicted that curriculum taught at AKESP primary schools was according to needs of students. Problems at AKESP schools were shortage of teachers, especially English teachers and lack of teaching aids. AKESP may take suitable measures to solve these problems. Researches can be planned to standards of quality primary education in AKESP primary schools and public sector primary schools, or differences in provision of facilities at AKESP's primary schools and public sector primary schools may be examined.
\end{abstract}

Keywords: Agha Khan educational services, Contribution, Facilities, Problems, Primary education, Chitral

\section{Introduction}

Education is a training process in which an individual is trained according to his/her mental caliber and capabilities in such a way as to be beneficial for whole society. According to Khan (1979) education is the initiation into what is worthwhile with the provision that what has been taught in a normally unobjectionable way. Formal education is purposive, self conscious and practical activity, which goes on in educational institutions. It presupposes two facts: that person is conscious and capable of thought; secondarily that person is capable of rational choice.

Education is the right of every child with out any discrimination of gender, race or region and it is the responsibility of every government to provide education facility to each and every child "Every one has right to get education" states that the universal declaration of human right (1989) citied in the national educational policy 1998-2010.

Primary level of education is considered as the basic or root level of education. According to Collins English Dictionary primary education means the education of child up to the age of eleven years. Generally it includes early five or six years of schooling.

Ghafoor and Farooq (1994) explain that primary education is the primary stage that last of five years and enrolls the children of 5-9 years. Khalid (1989) described, "Primary education is the most important sub sector of enter education system. It is foundation stone upon which the large building of the entire social, culture and economic development of a nation to be build."

Pakistan is a developing country; it needs a lot of progress in every field especially in education. The developments in other fields depend upon developments made in educational field. Primary education is an essential factor that plays an important role in the development of the country. Since its independence, Pakistan 
has made a lot of effort for the development and expansion of primary level of education. But lots of efforts still are needed in this area.

According to Tahir Andrabi, Jishnu Das and Asim Ijaz Khwaja (2002) since the denationalization of private schooling in Pakistan in 1979, there has been significant growth in the share of education in the private sector, both in terms of the numbers of schools, as well as the proportion of children enrolled.

Dr. Shami and Sabir (2005) in their report about basic education in Pakistan point out that apart from access, the quality of education is very poor, especially in the public sector and rural areas. A dilapidated infrastructure, lack of proper facilities, irrelevant curricula, etc., along with untrained teaching staff, staff absenteeism, paucity of books and teaching aids adversely affect the quality of education. This results in low levels of learning achievement, and wastage of resources through grade repetitions, and high drop-out rates. They further favoured the idea of role of non governmental organizations in promotion of basic education. According to them participation of local community at the grassroots level is key to the success of basic education programs, especially in the rural areas. This participation has been lacking in the countryside, where parents and communities neither understand the value of education nor contribute to it in any way.

Mr. Rohn the Consul General of the United States in Karachi, Douglas C. Rohn, while speaking at a launching workshop of the NGO Institutional Management and Certification Programme (IMCP) held here on Wednesday speaks that Pakistan has also an excellent record of civil society organizations' contributions to the country's social, economic and political development. He further appreciated efforts by the Aga Khan Foundation for civil society strengthening and socio-economic development in Pakistan. He also hoped that many NGOs would get benefit from this programme through different interventions of NGORC. He spoke about the size and challenges for the NGO sector. He said that according to recent study, there were approximately 45,000 active non-profit organizations in Pakistan. An online reference retrieved from: http://www.dawn.com/2004/04/08/nat 18.htm

Dr. Mustaghis-ur-Rahman (2004) points outs that NGOs at their own levels, without state's open-arm policies are playing important roles in achieving social targets, though at micro level. Grass roots organizations and intermediary NGOs are making numerous contributions to the sustainable development. They are mobilizing local people and resources to support projects with a motive to enable people to improve quality of life.

The AKRSP model was replicated by each of the four provinces in addition to the National Rural Support Programme (NRSP) at the national level. According to one estimate, by 2000, these rural support programmes had in turn formed more than

20000 village-based organizations across Pakistan and also a rural support network to share experiences and provide support to further their poverty reduction programme (online reference March 2010 retrieved from www.google.com).

\subsection{Creating Awareness about Social Needs and Issues}

"India, Pakistan, Bangladesh, Sri Lanka, Nepal, Bhutan and the Maldives continue to lag behind in meeting basic needs like education, health, and access to safe water, food security and elimination of gender disparity". (Dawn November 4, 2004).

Some NGOs in Pakistan have played an important role in creating awareness on issues such as human and legal rights, women's role in development, and over-population. For women and minorities that have borne the brunt of religious bigotry and social repression, civil society came as a silver lining in dark, gloomy clouds...... Civil Society's efforts gave an impetus to the government's slowly growing commitments towards greater gender equality, culminating in Pakistan ratifying the UN Convention on the Elimination of All Forms of Oppression against Women in 1996. The efforts of human rights advocates have led judicial institutions to consider the plight of rape victims, for example, and take their claims seriously. They have thus become more responsive to citizens than in the past. Today, the number of women organizing at grassroots level and establishing linkages with other institutions is remarkable, even though their impact at wider societal level is not so visible.

However, women across Pakistan still continue to fight against primitive social customs and discrimination. Civil society's efforts in this regard entail a slow process, as deep-rooted societal norms cannot be altered overnight.

\subsection{International Recognition}

These success stories have won acclaim at home and abroad. Seven Pakistani leaders - the late Akhtar Hameed Khan, Abdul Sattar Edhi, Bilquis Edhi, Dr. Adeeb Rizvi, Tasneem Siddiqui, Shoaib Sultan Khan and Asma Jehangir have been awarded the prestigious Ramon Magsaysay award. 
Dr. Mustaghis-ur-Rahman (2004) illustrates that in Pakistan hundreds of local NGOs are doing well, just to put an example, by many measures, the Aga Khan Rural Support Program (AKRSP) is a highly successful NGO-run rural development programme. It reaches some 900,000 people in about 1,100 villages in the Northern Areas and Chitral District of Pakistan, near the Afghanistan border. Retrieved on May 10, 2010 from: http://www.civicus.org/new/media/pakistan

Keeping in view the scenario of primary education in Pakistan some Non Government Organization (NGOs) has started to play their marvelous role in the development of primary level of education by providing educational facilities especially to deprived areas of Pakistan.

Such NGOs work in this area voluntarily. One of such prominent NGOs is Aga Khan Education services (AKES) is one of the largest private organization, which work for education in Pakistan. It is sub unit of Aga Khan Development Network (AKDN). The symbol of AKES is based on open book containing a double image of word IQRA (to read) from the first revolution of Allah to Prophet Muhammad (Sura 96: verses 19 of the Holy Quran).

The foundations of the present system were laid by Sir Sultan Muhammad Shah Aga Khan, III, who established over 200 schools during the first half of the $20^{\text {th }}$ century, the first in 1905 in mundra and Gwadur in India and another in Zanzibar followed by more schools in Kenya, Uganda, Tanzania, India, Pakistan and Syria. Sir Sultan Muhammad Shah also supported the development of institutions of higher education in India, and North and East Africa.

Today AKES is one of six agencies of the Aga Khan Development Network (AKDN) supporting activities in the field of education the other Three Are the Aga Khan Foundation (AKF), The Aga Khan University, The University of Central Asia, The Aga Khan Academies and the Aga Khan Trust for Culture (AKTC).

AKES currently operates more than 300 schools and advanced educational programmes that provide quality pre-school, primary, secondary, and higher secondary education services to more than 54,000 students in Pakistan, India, Bangladesh, Kenya, Ugenda, Tanzania, and Tajikistan. AKES is also developing new schools in Kyrgyzstan and Madagascar and studying the feasibility of services and facilities in Mozambique.

Programmes to improve educational quality have been built into the AKES system since the early-1980s. Field-based teacher training was launched in Pakistan's Northern Areas in 1983.School improvement experiments began at the same time in Sindh Province in Pakistan, where AKES introduced child-centered teaching methods, and in Tanzania, where new techniques for secondary school teaching in English, Mathematics, and Science were implemented in Dar es salam. AKES, Kenya has been the Development Network pioneer in the use of computers in the classroom, while many Network initiatives in pre-school education began in AKES, India.

Supported by the Aga Khan Foundation, some of these experiments have been carried out in government schools as well as AKESP institutions, thereby contributing to the improvement of education in the countries in which AKESP operates. With both the national service companies and the Aga Khan Foundation acting as relays, this body of experience in teacher development and school improvement is having an impact throughout the Network. The institute for Educational Development of the Aga Khan University was created to provide a permanent institutional base that can sustain these and other initiatives in education.

At present AKESP with 186 schools, 4 Hostels, Over 200 community based initiatives and 100 public and private partner's school provides educational access to over 75,000 students across Pakistan. With over 60\% female enrolment in Aga Khan Schools AKESP has played a critical role in the development of women in these regions. It is a torchbearer in the promotion of women development. Aga Khan Education Service Pakistan Continues to work with the government and communities to develop models of public /private partnership, which play a vital role towards implementing the education sectors reforms of the Ministry of Education.

Subsequently the Aga Khan Education Service Pakistan (AKESP) was established in Chitral in 1983 and operates 52 schools in Chitral and established one Aga Khan Girls Hostel in Booni. Some schools were established in Chitral in houses or in the corridor of mosque, or in temporary shelter, other operates under the open sky. In order to address this problem Aga Khan education Service Pakistan (AKESP) initiated the self-help schools construction program (SHSCP) in Chitral in 1998 over 500 educationally functional and seismic resistant classrooms have been constructed to date. There is a great role of AKESP in the promotion of primary education in Chitral District.

In the field of quality improvement the AKESP has introduced new horizons of teacher development and school support system. The different kinds of training in content and methodology provided by teachers of AKESP, 
Government of Pakistan and private English Medium schools has brought visible and positive changes in the quality of teaching by keeping the teachers abreast of new teaching methods.

Aga Khan Schools, offer student center of teaching and learning environments designed to stimulate the joy of inquiry. Students are encouraged to ask question and participate in co-curricular activities to develop their self-esteem, confidence, teamwork, self-discipline and sociability.

To nurture the crucial early years of child with care and proper acknowledgement of his innate potentials, Aga Khan School place especial emphasis on early childhood development while offering schooling for middle and senior years.

While following the national curriculum all Aga Khan schools focus on providing the students with holistic educational experiences that will polish their personalities and hone their skills, preparing them to shoulder their responsibilities as valuable member of their

Communities' especial emphasis is placed on the learning of Mathematics, English and Science (www.akesp.com.pk, retrieved on March 10, 2008).

\subsection{Objectives of Aga Khan Education Services Pakistan (AKESP)}

The objectives of AKESP are the followings:

a. Experimenting with models from which other education providers can benefit.

b. The importance of the widest possible across to education.

c. The importance of "quality" education.

d. The importance of female education as well as male education.

e. The development of female manpower and female teaching force.

f. The involvement of community in the education of its children's (IIahi, M.1996, www.google.com on March 10, 2008)

\subsubsection{Objectives of AKESP in Chitral}

a. To arranging meeting, seminars for the purpose of teacher are training in Chitral.

b. To provide the educational opportunity in Pakistan and outside the country.

c. To arrange impressive program with the help of Aga Khan Schools in Chitral.

d. To allocate special funds for special children.

e. To provide professional facilities.

f. To encourage and motivate teacher for further improvements.

g. To promote Islamic culture and Islamic vision in students

h. To provide the awareness of important of education in Chitral.

i. To motivate the people for regional development.

j. To improve the quality of basic education in Chitral.

k. To impart knowledge in caring and learning environment for young children's.

1. To rise the level of academic achievements.

m. To make the people of Chitral more civilized well educated and sound known citizen in the world.

$\mathrm{n}$. To encourage the development of local curriculum materials, and teaching aids by the teachers.

o. To impart meaningful education a" related to world of works".

p. To reverent curriculum with culture and economic.

q. TO enhance the educational opportunities.

r. To create sense of ownership in the society.

s. To teach the teachers the basic teaching skills.

t. To encourage the students and parents for the improvement of the education in Chitral. (www.akesp.org retrieved on 20-5-2008) 


\subsubsection{Aga Khan School Curriculums at Primary Level}

Whist each of the Aga Khan School complies with National Curriculum of Individual Countries, the service enrich the curriculum with various teaching methodologies that emphasize the student centered learning. All school offer student centered learning and teaching environment design to stimulate the joy of inquiry. Interactive education encourages student to ask questions, pursue independent lines of inquiry and develop interest and expertise in a broad range of knowledge. Co-curricular subject, such as music, art, and dance further can rich the curriculum. Extra curricular activities, like further school sports and clubs and programs of community service, play an important part in extending learning to less tangible qualities, such as self steam, self confidence, team work self discipline and sociability quality that play an important part in the development of student ethical system. (www.akesp.com.pk retrieved on August 05, 2008).

\subsubsection{Statement of the Problem}

Since AKESP one of the largest NGOs that is putting great efforts in Gilgit Baltistan. Therefore the present study was designed to investigate "Contribution of Aga Khan Education Service Pakistan (AKESP) at Primary Level in Chitral".

1.3.4 Objectives of the Study

The objectives of the study were

1. To measure the existing contribution of AKESP in the field of primary level education program at chitral.

2. To investigate the deficiencies (if any) of AKESP in the field of primary education program at Chitral.

1.3.5 Null Hypothesis

1. There is no contribution of AKESP for providing primary level education at Chitral.

2. There are no deficiencies in primary level education program of AKESP at Chitral.

\subsubsection{Methodology of the Study}

1.3.6.1 Population and Sampling: All primary schools run by AKESP located in District Chitral were the population of the study. There were totally 52 primary schools in Chitral. The sample for the study was selected randomly. Out of 52 primary level schools run by AKESP in Chitral, 15 schools were selected randomly. All Head Teachers and three (03) teachers serving in these 15 randomly selected schools were the subject of the study.

Number of schools $\quad=15$

Number of head teachers $\quad=15$

1.3.6.2 Chitral

Chitral is surrounded by three famous perpendicular mountain ranges, Hindukush with the towering terichmir (25263 feet) in the west, Hindu Raj to the east with numerous peaks of over 20,000 feet and the karakuram range crossing by the famous Shandure Pass (Highest polo ground in the world) at 12,220 feet. It shares these majestic mountain ranges with Afghanistan's Badakhshan province all along its north (a 150Km western stretch) and the northern area of Pakistan at its eastern border, spread over an area of 14,850 square kilometer. Due to these surrounding, Chitral has been and still is an isolated District of Northern of Western Frontier Province (NWFP, its new name of Khaiber Pakhtoon Khawa: KPK). These isolated coupled with limited cultivable land and lack of other opportunities left its inhabitants illiterate, poor and under privileged for centuries. According to the 1998 census report, Chitral, known as valleys, has a population of 360,000 people predominantly consisting of indigenous communities speaking different dialects but sharing Khowar as a common language. There is small a community of new settler from down country, mainly Pshtoon business families. In its diversity, Chitral is credited to be a place of security and survival for a very small ancient community Known as KALASH in the three narrow spectacular valley of bumburet, Birir and Rumbur. Close to $90 \%$ of Chitrals' population lives in rural settlements and only $41 \%$ has access to piped drinking water. About $67 \%$ population has access to electricity through Government and non-Government agencies.

When AKESP opened its first school in Chitral in early 1980s,female literacy was $2.3 \%$ which by 1998 had increased to $22.09 \%$. Today the literacy rate among the population aged 5 years and above, is estimated;male $58 \%$ and female $31 \%$.AKESP for over half a century has contributed substantially to education in Chitral. CHITRAL and Northern areas are located in the extreme north of Pakistan are characterized by very poor communications with the rest of the country. Until the construction of Lavertor this connects Chitral with Peshawar through dear 
and the construction of the Karakorum high way, which connects, Pakistan with china through the khunjarab pass, there was no all-weather link. Even today, many parts of the region are isolated during the winter, and flights to Chitral and Gilgit are subject to weather conditions throughout the year. (www.akesp.com.pk, www.chitralnews.com retrieved on March 29, 2008).

\subsubsection{Data Instruments}

The researchers as research instruments developed a questionnaire and it was used for data collection. Questionnaire was developed comprising questions regarding the contribution of AKESP in the field of primary level education in Chitral Questionnaire was designed for head teachers at primary level in Chitral. A team of experts from the National University of Modern Language Islamabad checked the validity of the instrument. After the validation by experts the instruments were administrated on the subjects.

\subsubsection{Delimitation}

There were many time and financial constraints; therefore the study was delimited to

1. Fifteen (15) randomly selected primary level schools at Chitral.

2. It was delimited to gathering data regarding facilities for students and teachers provided by AKESP.

3. It was delimited to gathering only through developed questionnaires by the researchers.

\section{3.6.5 Data Analysis and Interpretation of Data}

The data collected through questionnaire from head teachers of AKESP primary level were analyzed by using chi-squire test.

Insert table No. 1 here

\subsection{Data Analysis of Questionnaire}

Insert table No. 2 here

It is obvious from above table No. 1 and No. 2 that majority of head teachers in AKESP primary level schools at Chitral have B. A academic and B. Ed professional qualification.

Insert table No. 3 here

Table No. 3 shows that the calculated value of $\mathrm{X}^{2}$ is found $\mathrm{t} 15$ and it is greater than the tabulated value, hence the null hypothesis that "AKES" does not give free admission for all the students" is rejected due to the chi-squire value.

Insert table No. 4 here

Table No. 4 explores that the calculated value of $\mathrm{X}^{2}$ is found 15 and it is greater than the tabulated value, hence the null hypothesis that "AKES does not provide medical facility to teachers" is rejected.

Insert table No. 5 here

Table No.5 reflects that the calculated value of $\mathrm{X}^{2}$ is found 8.066 and it is greater than the tabulated value, hence the null hypothesis that "AKESP" does not provide proper building facility" is rejected.

Insert table No. 6 here

Table No.6 depicts that the calculated value of $\mathrm{X}^{2}$ is found 15 and it is greater than the tabulated value, hence the null hypothesis that "AKES does not provide furniture facility" is rejected.

Insert table No. 7 here

Table No. 7 depicts that the calculated value of $\mathrm{X}^{2}$ is found 15 and it is greater than the tabulated value, hence the null hypothesis that "AKES does not provide electricity facility" is rejected.

Insert table No. 8 here

Table No. 8 explains that the calculated value of $\mathrm{X}^{2}$ is found 2.7 and it is greater than the tabulated value, hence the null hypothesis that "AKES does not provide computer facility" is rejected.

Insert table No. 9 here

Table No. 9 reflects that the calculated value of $\mathrm{X}^{2}$ is found to 5.4 and it is greater than the tabulated value, hence the null hypothesis that "AKES does not provide sick room facility" is rejected.

Insert table No. 10 here 
Table No. 10 describes that the calculated value of $\mathrm{X}^{2}$ is found to 15 and it is greater than the tabulated value, hence the null hypothesis that "AKES does not provide award scholarship to out standing students" is rejected.

Insert table No. 11 here

Table No. 11 explains that the calculated value of $\mathrm{X}^{2}$ is found to 8.066 and it is greater than the tabulated value, hence the null hypothesis that "AKES does not provide free concession facility for poor students" is rejected.

Insert table No. 12 here

Table No. 12 depicts that the calculated value of $\mathrm{X}^{2}$ is found to 15 and it is greater than the tabulated value, hence the null hypothesis that "AKES does not arrange refresher courses" is rejected.

Insert table No. 13 here

Table No. 13 shows that the calculated value of $\mathrm{X}^{2}$ is found to 45 and it is greater than the tabulated value, hence the null hypothesis that" AKES does not provide proper Drinking water facility" is rejected.

Insert table No. 14 here

Table No. 14 depicts that the calculated value of $\mathrm{X}^{2}$ is found 8.06 and it is greater than the tabulated value, hence the null hypothesis that" AKES does not provide proper toilet facility" is rejected.

Insert table No. 15 here

Table No. 15 shows that the calculated value of $\mathrm{X}^{2}$ is found 5 and it is greater than the tabulated value, hence the null hypothesis that" content at primary level does not according to students needs "is rejected.

Insert table No. 16 here

Table No. 16 describes that the calculated value of $\mathrm{X}^{2}$ is found to 21.34 and it is greater than the tabulated value, hence the null hypothesis that" teaching skill does not improve due to these refresher courses "is rejected.

Analysis of Head Teachers open Ended Views about Major Problems at AKESP Primary Schools: The head teachers answer asked to write the problems that they are facing at AKESP primary level schools. The common picture of problems that emerges from head teachers views is depicted below:

1. Shortage of teachers

2. Huge number of students

3. Lack of provision of teaching aids

4. Shortage of English teachers

It is reflected from the above table of open ended questions from head teachers that majority of head teachers of AKESP primary schools faced the problems of shortage of teachers in their respective school and equally important is the problems of shortage of qualified teachers.

\section{Conclusions and Recommendations}

From data analysis as mentioned in above pages it is obvious that AKESP is contributing a lot in providing primary education facilities at Chitral.

It is obvious fro data analysis that majority of teachers working at AKESP primary level schools at Chitral have B. A/ BSc (Bachelor of Arts/ Bachelor of Science) as their educational and B. Ed/ BS. Ed as their professional qualification. That means AKESP appoints qualified teachers at their primary level schools for the purpose of achieving quality education in their institutions.

It was found that all students who apply for admission are granted free admission in AKESP schools.

1. It was found that all students who come for admission are granted admission in AKESP. Therefore it is obvious that AKESP follows the motto of "Education for All".

2. It is obvious from findings that majority of head teachers in AKESP primary level schools at Chitral have B. A academic and B. Ed professional qualification.

3. AKESP provides medical facility to teachers. It can be concluded that in AKESP there are qualified teachers at primary level that will definitely raise the quality of education in that area.

4. Findings report that AKESP arranges refresher courses for teachers in order to improve and refresh their teaching skills and knowledge. 
5. AKESP provides proper building, furniture, electricity, computer facility, library facility, sick room facility, drinking water facility, proper toilet facility, and scholarship facility to outstanding students and fee concession facility for poor students in AKESP primary schools.

6. So far as curriculum at AKESP primary schools is concerned findings explain that content taught at AKESP primary level schools is according to students needs.

7. The common picture of problems that emerges from head teachers views is depicted below:

$\checkmark$ There is shortage of teachers at AKESP centers

$\checkmark$ Teachers are not satisfied with current salary status

$\checkmark$ Huge number of students

$\checkmark$ Lack of provision of teaching aids

$\checkmark$ Proficiency in English language teaching

From the finings of the study it is obvious that AKESP is performing a lot for promotion of primary education in Chitral. Findings depicted that curriculum taught at AKESP primary schools are according to various needs of students. It is pointed out by principal of AKESP that there is still shortage of teachers as compared to strength of students, lack of teaching aids and principals feel that they need proficient teachers for English language teaching. Keeping in view the findings of the present study it is recommended as the present study was conducted to asses AKESP's contribution in the field of primary education.

A further study can be planned to find AKESP's contrition in the field of secondary education. The status of quality education at AKESP primary education schools/ centers and the status of quality education in other areas of Pakistan can be investigated. The status of provision of facilities at AKESP's primary schools and at primary schools of Government of Pakistan can be determined through further exploration of facts.

\section{References}

Ahmed, M. And Ghaus k., (ed.). (1999). Pakistan: Prospects and Perspectives. Karachi: Royal Book Company. Census Report. (1998). Statistics Division. Ministry of Information, Islamabad.

Asian Development Bank. (2000). Report. Women in Pakistan.

Bajwa.z. (1992). The Non-Profit Sector: Nongovernmental Agencies and Entrepreneurship in Pakistan. PhD dissertation, Cornell University, 1992.

IIahi, M. (1996). Online reference. [Online] Available: www.google.com (March 10, 2008).

Mustaghis-ur-Rahman, Dr. (08 November 2004). Role of NGOs in the social sector. [Online] Available: http://dawn.com (May 12, 2010).

Raza R. (1997). Pakistan in Perspective, 1947-1997. UK: Oxford University Press.

Shami. P.A. Dr. and Kh. Sabir Hussain. (2005). Basic Education in Pakistan. AEPAM Research Study No. 181. Islamabad. Academy of Educational Planning and Management Ministry of Education. January 2005.

Tahir Andrabi Jishnu Das Asim Ijaz Khwaja. (March, 2002). The Rise of Private Schooling in Pakistan: Catering to the Urban Elite or Educating the Rural Poor. 2011 [Online] Available: www.google.com (20 January).

[Online] Available: http://www.civicus.org/new/media/pakistan

[Online] Available: www.akesp.com.pk, www.chitralnews.com retrieved on March 10, 2008).

[Online] Available: www.dawn.com/2004/04/08/nat18.htm. Dawn April 08, 2004, 08 November 2004

[Online] Available: www.akesp.org retrieved on 20-5-2008).

The summary of data analysis and interpretation is given below:

\section{Demographic Data}

Table 1. Professional qualification of Head Teachers

\begin{tabular}{|c|c|c|c|c|}
\hline No. of head teachers & M. Ed & B. Ed/ BS. Ed & C.T & PTC \\
\hline \multirow{2}{*}{15} & 2 & 8 & 3 & 2 \\
\cline { 2 - 5 } & $13.33 \%$ & $53.33 \%$ & $20 \%$ & $13.33 \%$ \\
\hline
\end{tabular}


Table 2. Academic qualification

\begin{tabular}{|c|c|c|c|}
\hline $\begin{array}{c}\text { No. of head } \\
\text { teachers }\end{array}$ & M.A/M Sc & B.A/ B Sc & $\begin{array}{c}\text { Service status } \\
\text { Permanent }\end{array}$ \\
\hline 15 & 2 & 13 & 15 \\
\cline { 2 - 4 } & 13.33 & 86.67 & $100 \%$ \\
\hline
\end{tabular}

Table 3. Admission criteria

\begin{tabular}{|l|c|c|c|}
\hline \multicolumn{1}{|c|}{ Statement } & respondents & Yes & No \\
\hline \multirow{2}{*}{$\begin{array}{l}\text { All students who come for } \\
\text { admission get admission in the } \\
\text { school. }\end{array}$} & fo & 15 & 0 \\
\cline { 2 - 4 } & $\mathrm{fe}$ & 7.5 & 7.5 \\
\cline { 2 - 4 } & $\mathrm{Fo}-\mathrm{fe}$ & 7.5 & -7.5 \\
\cline { 2 - 4 } & $(\mathrm{fo}-\mathrm{fe})^{2}$ & 56.25 & 56.25 \\
\cline { 2 - 4 } & $(\mathrm{fo}-\mathrm{fe})^{2} / \mathrm{fe}$ & 7.5 & 7.5 \\
\cline { 2 - 4 } & \multicolumn{3}{|c|}{$\sum(\mathrm{fo}-\mathrm{fe})^{2} / \mathrm{fe}=\mathrm{X}^{2}=15$} \\
\hline
\end{tabular}

Significant*

$\mathrm{df}=1$

Level of significant $=0.05$

Tabulate value $=3.841$

Calculated value $=15$

Table 4. Medical facility to teachers

\begin{tabular}{|c|c|c|c|}
\hline Statement & Respondents & Yes & No \\
\hline \multirow{6}{*}{$\begin{array}{l}\text { AKESP provides medical } \\
\text { facility to teachers of the } \\
\text { school. }\end{array}$} & Fo & 15 & 0 \\
\hline & $\mathrm{Fe}$ & 7.5 & 7.5 \\
\hline & Fo-fe & 7.5 & -7.5 \\
\hline & $(\text { fo-fe })^{2}$ & 56.25 & 56.25 \\
\hline & $(f o-f e)^{2} / f e$ & 7.5 & 7.5 \\
\hline & \multicolumn{3}{|c|}{$\sum(\mathrm{fo}-\mathrm{fe})^{2} / \mathrm{fe}=\mathrm{X}^{2}=15$} \\
\hline
\end{tabular}

Significant*

$\mathrm{df}=1$

Level of significant $=0.05$

Tabulate value $=3.841$

Calculated value $=15$

Table 5. Proper building facility for teachers

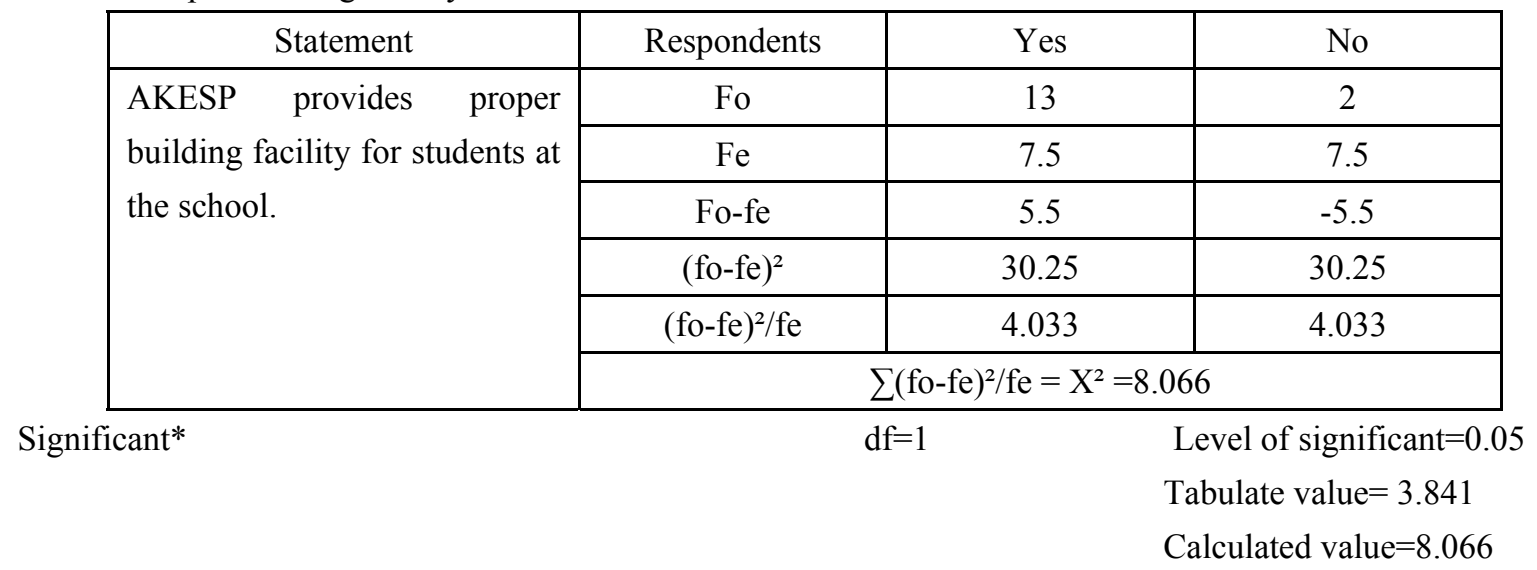


Table 6. Proper furniture facility

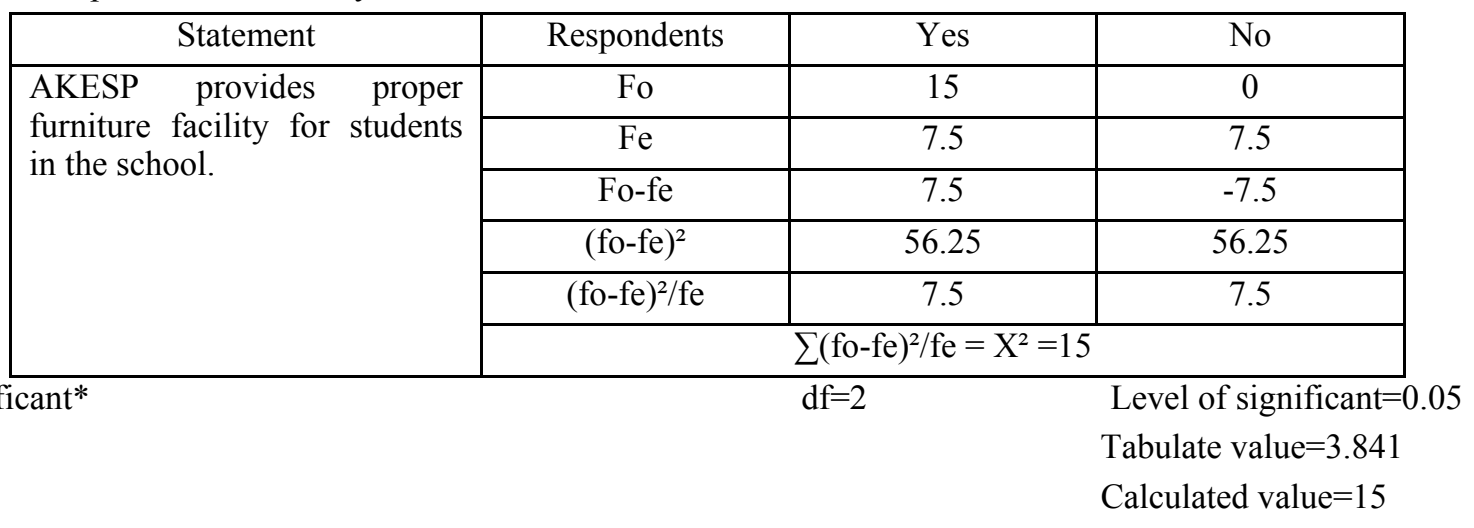

Table 7. Electricity facility

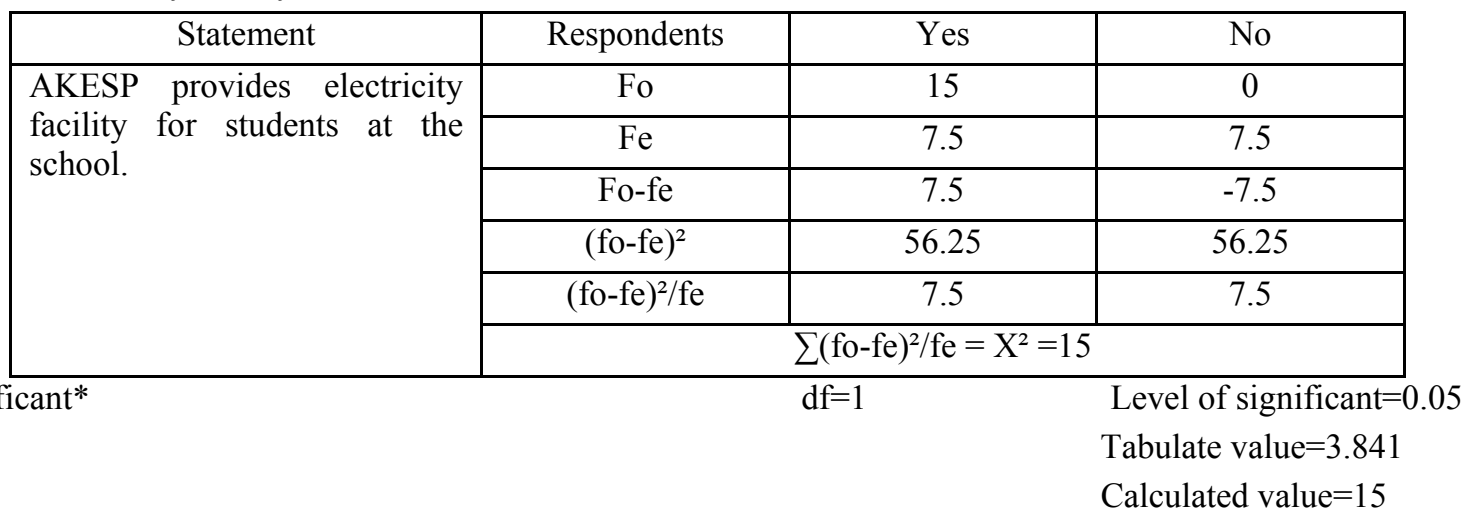

Table 8. Computer facility

\begin{tabular}{|c|c|c|c|}
\hline Statement & respondents & Yes & No \\
\hline \multirow{4}{*}{$\begin{array}{c}\text { AKESP provides computers } \\
\text { for students at the school. }\end{array}$} & $\mathrm{fo}$ & 12 & 3 \\
\cline { 2 - 4 } & $\mathrm{fe}$ & 7.5 & 7.5 \\
\cline { 2 - 4 } & $\mathrm{fo}-\mathrm{fe}$ & 4.5 & -4.5 \\
\cline { 2 - 4 } & $(\mathrm{fo}-\mathrm{fe})^{2}$ & 20.25 & 20.25 \\
\cline { 2 - 4 } & $(\mathrm{fo}-\mathrm{fe})^{2} / \mathrm{fe}$ & 7.5 & 7.5 \\
\cline { 2 - 4 } & \multicolumn{3}{|c|}{$\sum(\mathrm{fo}-\mathrm{fe})^{2} / \mathrm{fe}=\mathrm{X}^{2}=5.4$} \\
\hline \multirow{3}{*}{$\mathrm{df}=1$} & $\begin{array}{c}\text { Level of significant }=0.05 \\
\text { Tabulate value }=3.841 \\
\text { Calculated value }=5.4\end{array}$
\end{tabular}

Table 9. Sick room facility

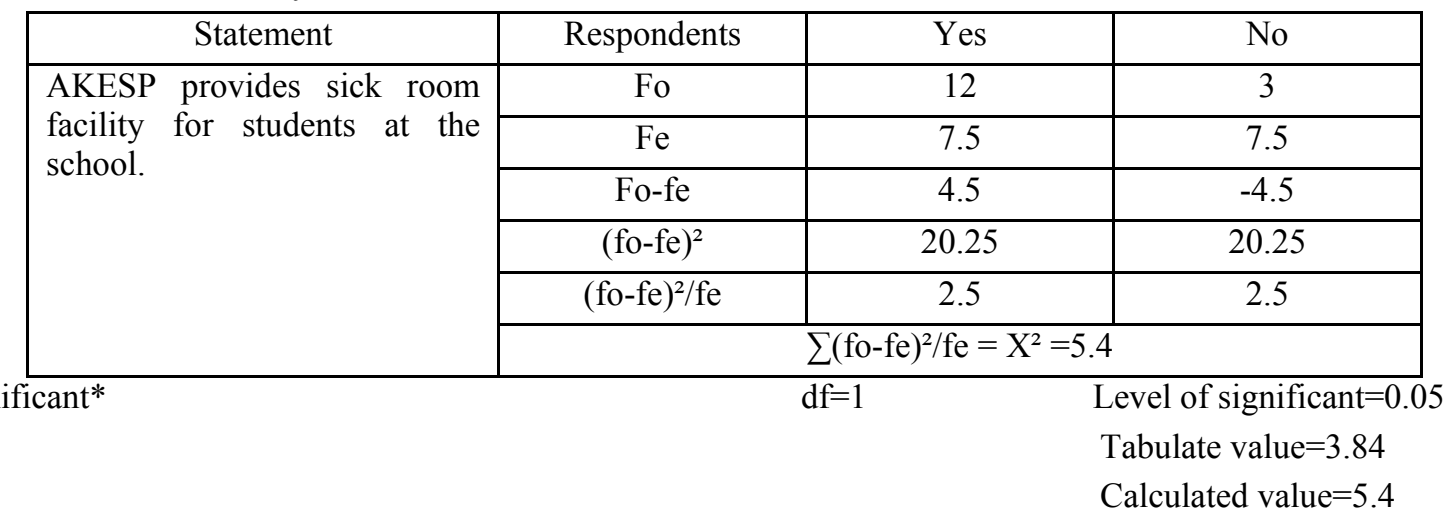


Table 10. Award scholarship to outstanding students

\begin{tabular}{|l|c|c|c|}
\hline \multicolumn{1}{|c|}{ Statement } & respondents & Yes & No \\
\hline $\begin{array}{l}\text { AKESP awards scholarships to } \\
\text { outstanding students of the } \\
\text { school. }\end{array}$ & fo & 15 & 0 \\
\cline { 2 - 4 } & fe & 7.5 & 7.5 \\
\cline { 2 - 4 } & Fo-fe & 7.5 & -7.5 \\
\cline { 2 - 4 } & $(\text { fo-fe })^{2}$ & 56.25 & 56.25 \\
\cline { 2 - 4 } & $(\mathrm{fo}-\mathrm{fe})^{2} / \mathrm{fe}$ & 7.5 & 7.5 \\
\cline { 2 - 4 } & \multicolumn{3}{|c|}{$\sum$ (fo-fe $)^{2} / \mathrm{fe}=\mathrm{X}^{2}=15$} \\
\hline
\end{tabular}

Significant* $\mathrm{df}=1$

Tabulate value $=3.84$

Calculated value $=15$

Table 11. Fee concession facility for poor students

\begin{tabular}{|c|c|c|c|}
\hline Statement & respondents & Yes & No \\
\hline \multirow{4}{*}{$\begin{array}{l}\text { AKESP informs the school } \\
\text { about its fee concession policy } \\
\text { for poor students. }\end{array}$} & fo & 15 & 0 \\
\cline { 2 - 4 } & $\mathrm{fe}$ & 7.5 & 7.5 \\
\cline { 2 - 4 } & $\mathrm{Fo}-\mathrm{fe}$ & 5.5 & -5.5 \\
\cline { 2 - 4 } & $(\mathrm{fo}-\mathrm{fe})^{2}$ & 30.25 & 30.25 \\
\cline { 2 - 4 } & $(\mathrm{fo}-\mathrm{fe})^{2} / \mathrm{fe}$ & 4.033 & 4.033 \\
\cline { 2 - 4 } & \multicolumn{3}{|c|}{$\sum(\mathrm{fo}-\mathrm{fe})^{2} / \mathrm{fe}=\mathrm{X}^{2}=8.066$} \\
\hline \multirow{3}{|c|}{$\mathrm{df}=1$} & $\begin{array}{c}\text { Level of significant }=0.05 \\
\text { Tabulate value }=3.841 \\
\text { Calculated value }=8.066\end{array}$
\end{tabular}

Table 12. Refresher courses for teachers

\begin{tabular}{|c|c|c|c|}
\hline \multicolumn{1}{|c|}{ Statement } & respondents & Yes & No \\
\hline \multirow{3}{*}{$\begin{array}{l}\text { AKESP arranges refresher } \\
\text { courses for the schoolteachers } \\
\text { form time to time. }\end{array}$} & Fo & 15 & 0 \\
\cline { 2 - 4 } & $\mathrm{Fe}$ & 7.5 & 7.5 \\
\cline { 2 - 4 } & $\mathrm{Fo}-\mathrm{fe}$ & 7.5 & -7.5 \\
\cline { 2 - 4 } & $(\mathrm{fo}-\mathrm{fe})^{2}$ & 56.25 & 56.25 \\
\cline { 2 - 4 } & $(\mathrm{fo}-\mathrm{fe})^{2} / \mathrm{fe}$ & 7.5 & 7.5 \\
\cline { 2 - 4 } & \multicolumn{3}{|c|}{$\sum(\mathrm{fo}-\mathrm{fe})^{2} / \mathrm{fe}=\mathrm{X}^{2}=15$} \\
\hline \multirow{2}{*}{$\mathrm{df}=1$} & \multicolumn{2}{|c|}{$\begin{array}{l}\text { Level of significant }=0.05 \\
\text { Tabulate value }=3.841 \\
\text { Calculated value }=15\end{array}$}
\end{tabular}

Table 13. Proper drinking water facility

\begin{tabular}{|l|c|c|c|}
\hline Statement & respondents & Yes & No \\
\hline \multirow{2}{*}{$\begin{array}{l}\text { AKESP has made arrangement } \\
\text { for drinking water facility for } \\
\text { students at the school. }\end{array}$} & Fo & 15 & 0 \\
\cline { 2 - 4 } & $\mathrm{Fe}$ & 7.5 & 7.5 \\
\cline { 2 - 4 } & $\mathrm{Fo}-\mathrm{fe}$ & 7.5 & -7.5 \\
\cline { 2 - 4 } & $(\mathrm{fo}-\mathrm{fe})^{2}$ & 56.25 & 56.25 \\
\cline { 2 - 4 } & $(\mathrm{fo}-\mathrm{fe})^{2} / \mathrm{fe}$ & 7.5 & 7.5 \\
\cline { 2 - 4 } & \multicolumn{3}{|c|}{$\sum(\mathrm{fo}-\mathrm{fe})^{2} / \mathrm{fe}=\mathrm{X}^{2}=15$} \\
\hline \multicolumn{3}{|c|}{$\mathrm{df}=1 \quad \begin{array}{l}\text { Level of significant }=0.05 \\
\text { Tabulate value }=3.841 \\
\text { Calculated value }=15\end{array}$}
\end{tabular}


Table 14. Proper toilet facility

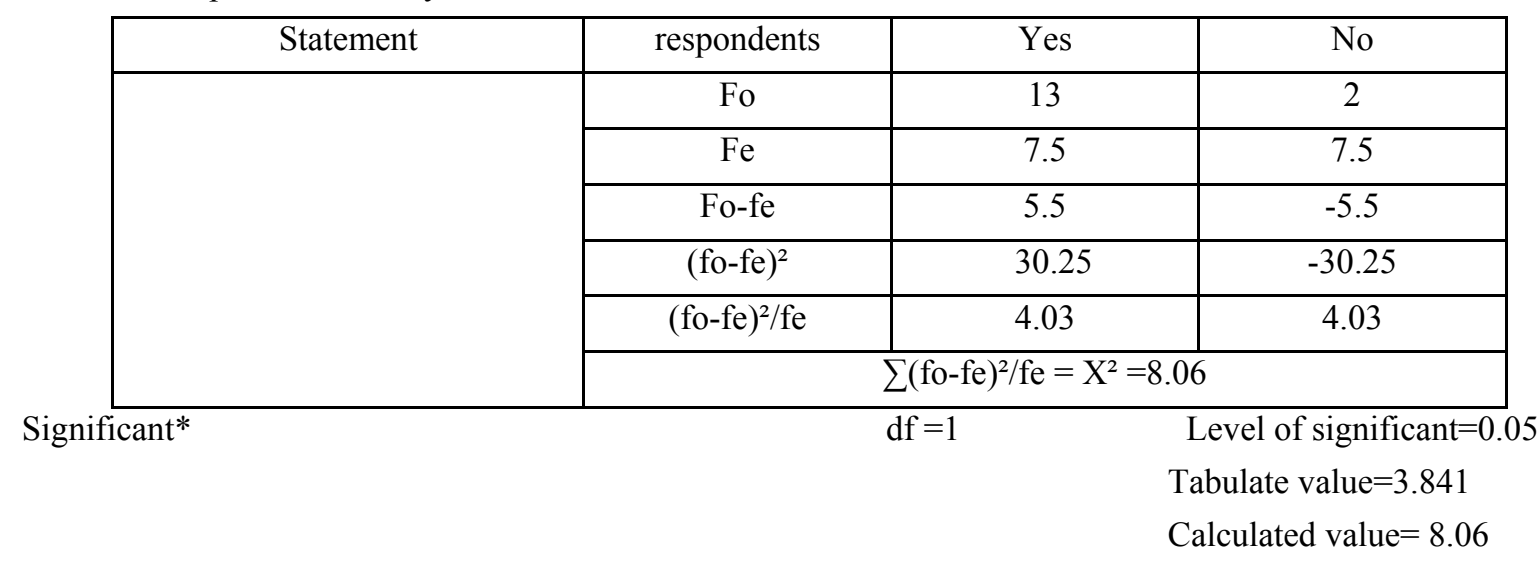

Table 15. Curriculum is according to students' need

\begin{tabular}{|l|c|c|c|}
\hline \multicolumn{1}{|c|}{ statement } & respondents & Yes & No \\
\hline \multirow{4}{*}{$\begin{array}{l}\text { AKESP curriculum is } \\
\text { according to students' need. }\end{array}$} & fo & 30 & 15 \\
\cline { 2 - 4 } & fe & 22.5 & 22.5 \\
\cline { 2 - 4 } & Fo-fe & 7.5 & -7.5 \\
\cline { 2 - 4 } & $(\mathrm{fo}-\mathrm{fe})^{2}$ & 56.25 & 56.25 \\
\cline { 2 - 4 } & $(\mathrm{fo}-\mathrm{fe})^{2} / \mathrm{fe}$ & 2.5 & 2.5 \\
\cline { 2 - 4 } & \multicolumn{3}{|c|}{$\sum(\mathrm{fo}-\mathrm{fe})^{2} / \mathrm{fe}=\mathrm{X}^{2}=5$} \\
\hline \multirow{3}{*}{$\mathrm{df}=1$} & $\begin{array}{c}\text { Level of significant }=0.05 \\
\text { Tabulate value }=3.841 \\
\text { Calculated value }=5\end{array}$
\end{tabular}

Table 16. Improvement of teaching skill through refresher courses

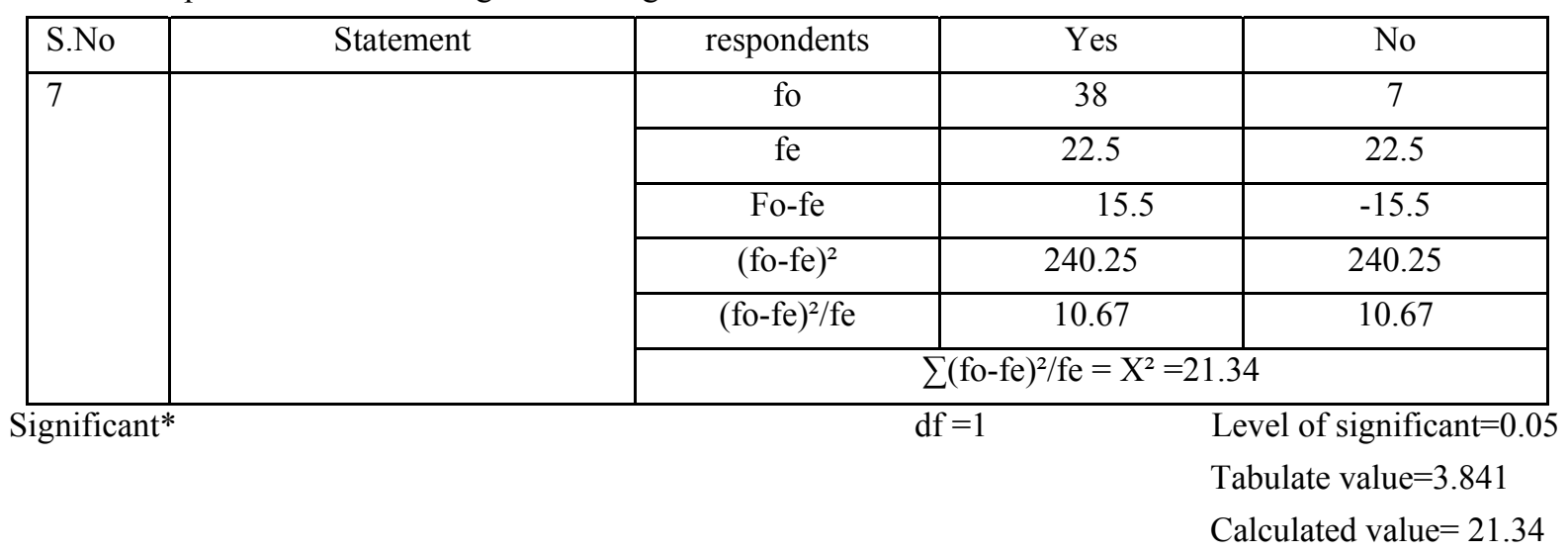

